\title{
Media Power Practices in Building a Frame of Economic and Political News During The Presidential Election Campaign of The Republic of Indonesia 2019
}

\author{
Siap Bangun Negara ${ }^{1}$, Udi Rusadi ${ }^{2}$ \\ Institut Ilmu Sosial dan Ilmu Politik Jakarta, Indonesia ${ }^{1,2}$ \\ \{siaptopskor@gmail.com¹, firusadi51@gmail.com²\}
}

\begin{abstract}
This study departs from a theoretical problem that the media must be free from all pressures and influences from both inside and outside parties in addition to serving the public interest. But the phenomenon is that there is still a strong influence of capital owners on media content. The inclusion of Republika's media leader, Erick Tohir, in the Presidential Candidate and Vice President No. 1 winning team in the 2019 Election, will have consequences for the process of producing news and the content it produces. This study aims to explore how the practice of power relations in building a frame in the production of news content and how the frame formed in the General Election of President and Vice President 2019-2024. The theory used is the theory of social reality construction, political economy economic theory, news production and framing theory. The framing method is used to examine the process of building a frame through interviews, observation, while to examine the news frame is used a text analyst that is the Entman model framing analysis. The results showed that in the process of building a news frame, the media crew claimed there was no intervention from the media owner who only explained his position, duties and functions as the head of the winning team for the Presidential Candidate and Vice President No. 1, while framing analysts' results show that Republika news frames in the economy illustrate positive performance which indirectly provides support to the candidate. From these it can be concluded that in the frame construction there has been a dominant hegemonic power relation that produces news frames that benefits the candidates.
\end{abstract}

Keywords: Power Practices; Frame Building; News Framing; Campaigns

\section{Introduction}

In principle, the media are required to be free from all influences, because the media are actually serving the public interest. But talking about media independence, until now, there is no media that is truly ideal and free from intervention. Not only in Indonesia, but even in America and Europe similar phenomena occur, where economic and political pressure on the mass media also exists. Not much different from in the United States (US). Chomsky and 
Herman use the concept of The Propaganda Model and see that the mass media in the US tends to depend on sources of information that come from the elite [1]. There has also been a tendency for the media to participate in propaganda campaigns that support the interests of the elite.

Political elite intervention is more easily seen in the coverage of the General Election process, as found in the study of Catrina which concluded that there was a strong influence of capital owners on media content during the 2014 election period [2]. The existence of political affiliation made it difficult for the media to separate political interests in decision the news. The reason, a number of presidential candidates who took part in the 2014 presidential election are the owners of a media group. For example, Aburizal Bakrie with the Viva group, Surya Paloh with the Media Group, and Hari Tanoesoedibjo with the MNC Group. The influence of capital owners and media owners has disrupted the independence and neutrality of media organizations. The mass media is experiencing economic and political pressure in formulating editorial policies. Catrina mentions that due to political affiliation, the media have difficulty in separating political interests in reporting decisions [2]. Not only refracting the function of the mass media, the intervention of the owners of capital on media content has a negative impact on the development of media independence and limits media movement. Interventions of various interests will arise in the mastery of public opinion as stated by D'Angelo, critical scholars often look at public opinion in the aggregate to show how public opinion is dominated by media frames [3]. In the framing process media organizations use their power in news selection (its function as a gate keeper) to frame news content. In this sense, the media not only provides information, but can also become autonomous actors in the political process.

Related to the power relations in the practice of the media, in the general election process in Indonesia in 2019, there was the phenomenon of the pair-vice presidential candidate number 01 (Jokowi-Ma'ruf Amin) making Erick Thohir as the Chairperson of the Indonesian National Coalition Working Team that supported the Jokowi pair -Ma'ruf. As is known, Erick Thohir is known as a media businessman, where the Republika newspaper is under the auspices of his Mahaka Group. Judged by researchers to have a strong political content. The researchers' assumption is that this phenomenon can influence the frame of news that provides support to the pair of President and Vice President No. 1. This study aims to answer the question, is there a practice of power relations in the process of building news frames, and what frames are built up. To prove this research will focus on economic and political news, because the issue is an issue that is directly related to the public interest.

\section{Method}

This research uses a critical paradigm in line with what D'Angelo stated that in framing analysis studies can use multiple paradigms, namely constructivist, cognitive, and critical paradigms [3]. In framing analysis studies that use constructivist paradigms tend to be able to build a theory. Whereas the cognitive paradigm connects how the influence of individual frames with news frames. Meanwhile, framing analysis with a critical paradigm can probe the extent to which media routines and journalist professional values enhance the democratic climate for individuals and community groups. The critical aspect in this research is to make an effort to study the power practices that occur in the democratic process, to reveal whether the dominance of the news frame is due to the power practices in the news production process in the Republika newspaper. Departing from the critical paradigm, this study uses a qualitative 
approach. This qualitative research is carried out by observing objects in research phenomena to understand and study the problems related to language and terminology from the actors involved in them. Kirk and Miller explain that qualitative research is a particular tradition in social science that fundamentally depends on observing humans in their own region and relating to these people in their language and terminology [4].

The frame building of economic and political news is examined by examining the process of input, process and news coverage [5] by conducting in-depth interviews with journalists, Republika media editors and conducting observations and discussions on the news production process in the newsroom. To prove what happens in the next frame buliding process, media text analysis is carried out with the Entman framing analysis model which suggests that frames in the news can be examined and identified by the presence or absence of certain keywords, stock phrases, stereotypical images, sources of information and sentences which provides thematic clusters that reinforce facts or judgments [6]. Thematic cluster consists of several attributes: Define problems/Problem Identification, Diagnosis of Causes/Causal Interpretation (Estimating the cause/source of the problem), Make Moral Judgment/Moral Evaluation (Making moral decisions/Assessing the cause of the problem), Treatment Recommendation (Emphasize completion).

The unit of analysis and the object of text studied in this study are headlines related to economic and political issues that were restricted during the 2019 Presidential Election campaign period (September 23, 2018 - April 13, 2019). During this period the researchers then sorted out the number of news related to economic and political issues during the 2019 Presidential Election campaign in the Republika newspaper and selected 10 headlines plus one Erick Thohir column on page one as the unit of analysis that was determined by the purposive sampling technique. which is not random where the researcher determines the sampling by determining the sampling and assigning special characteristics that fit the purpose of the study so that later it can answer the research problem.

\section{Results and Discussion}

One thing that needs to be noted here is that every news topic proposal that will be raised tomorrow starts from the formation and construction of a frame (frame-building) from the framing side in the newsroom, of course it has been adjusted to the influence of internal factors such as Republika's editorial policies and the value of the news itself to the individual influence of the reporter who wrote the news and the editor who did the editing, as well as the signs of the media owner. While the influence of external factors involved in this process can occur due to the influence of news sources, advertising sources/from readers, to the influence of the government and the environment. The reporter's proposal will then be updated in the morning until noon by each of the assistant editors/editors. Especially if new issues occur or new issues emerge that make it more interesting and must get more portions to be reported to the public. After the reporting process, all material to be written has been collected in the newsroom section and will be discussed in advance in the editorial meeting every afternoon attended by the editor in chief or its representative, the coverage coordinator, managing editor, newsroom head, executive editorial assistant, editor, assistant editor, to from the advertising section. From this editorial meeting, it will be known which news and photos will fill each page, which will also determine which issues will be the headlines for each page, including page one. After each news file is written and sent by the reporter, then each leader will do the editing. After that the results will be sent to the visual section for lay-out per page. After the 
printing results will come out in black and white for the final correction before the file is sent to the printing press to be reproduced according to the number of copies recorded to be produced. This editorial workflow will be repeated every day in the news production process in the Republika newspaper which was referred to as media routine as one of the factors that influence decision making in the newsroom.

In the process Republika embraced the moderate Islamic ideology brought by Erick Thohir as the second owner of Republika after the ICMI era. Towards the 2019 Presidential Election campaign period, Erick is believed to be the head of the national campaign team of the presidential and vice presidential candidate pair number 01. Erick Thohir's attitude is the central figure in Republika according to Asisstant Managing Editor of the Republika Newspaper Stevy Maradona. Not to restrain or to be interpreted has given the green light in the form of freedom to the Republika editors to manage the content of the news as an independent entity in building a frame (frame building), especially any economic and political reporting during the 2019 Presidential Election campaign period. to side with Presidential Candidates and Vice President No.1. Framing analysis is carried out on Republika newspaper headlines during the 2019 Presidential Election campaign period, starting from the 23 September 2018 edition until 13 April 2019. The purpose of the framing analysis is to find out whether Republika's economic and political news frames news that supports the ongoing government .

The study focused on 10 headlines that appeared in 10 editions of the Republika newspaper plus one column on page one that contained economic and political-themed news during the 2019 Presidential Election campaign period. From the 10 news analyzed, Republika framed the Indonesian economy in a positive condition. Positive issues revealed were stronger investor confidence, majority ownership of Freeport shares that would prosper Papuans, exceeding state revenues, declining fuel prices, the inauguration of the MRT as a new civilization in the field of transportation, and the struggle against European policies that discriminate against palm oil exports from Indonesia and Malaysia. As a cause of a strong Indonesian economy, Republika said that because of increasing foreign capital flowing into Indonesia, the impact on the rupiah's position was stronger. The problem of ownership of the majority of Freeport shares, which has a lot of pros and cons, Republika gives the frame to bring ownership of shares as an action that will prosper the people of Papua. This assessment is based on information that Indonesia has completed the Preeport share divestment. Another positive frame can be seen from the news about the attention of the government and regulations on people with disabilities to obtain employment, falling fuel prices.

In the political sphere highlighted is the issue of the 212 reunion, namely the reunion of the Muslim movement on December 2, protesting the blasphemy by the DKI Governor, Basuki Tjahaja Purnama, commonly called Ahok. This article frames the position of Erik Tohir, the leader of Republika, giving the view that the reunion of 212 should not be linked to the political agenda, and directing that Republika gives freedom in carrying out coverage of the event. The frame is built by selecting certain issues and ignoring other issues is a discourse strategy, namely by using a prominent placement in this case on the headlines. There were also many repetitions to the use of graphics to support and strengthen the prominence of what Republika wanted to convey to its readers regarding their editorial policies.

The practice of media power is carried out by Republika in the scope of allocative and operational power as said by Murdock in Gurevitch, Bennet, Curran [7]. In the scope of allocative power, occurs when the media leader in this case Erik Tohir distributes power to the elements of the organizational structure below him, namely the editor and reporters to direct the process of reporting and reporting news. The practice of operational power is seen by the 
editors and reporters making decisions independently in deciding the news and news frames that are built. From the key informants of this study, it was found that individual factors, routine media and organizations, external and ideology support the realization of balanced news in accordance with normative journalistic rules. Individually, at the leadership level there is no specific direction on how to cover issues that are grazing towards accentuating or siding with one of the pairs of presidential and vice presidential candidates regarding reporting in the economic and political fields during the 2019 election campaign period. "As a general guide , he (Erik Tohir) said that the two candidates were the two best people of Indonesia. Republika supports the best ideas from both candidates, especially those that prioritize the economic interests of the people. That also applies in the content production process. "

The general rule of journalism seems to be enough to guide Republika journalists in writing wise news, especially when grazing on economic and political issues. Republika journalists are required to continue to put the event in proportion and write it as a news product. They submit to the community the assessment or consequences that may arise from the news. Judging from the routine work of the media crew, it is seen that there is a patterned work system, so that the birth of work is more affective and accurate. The news frame during the 2019 Presidential Election campaign period was only slightly adjusted for certain issues, that is, as said earlier, editors must be more observant in sorting out the facts and comments from the paslon and their campaign team that are more in line with the news frame itself. If indeed the facts and comments are better than other parties, then of course the facts and comments will get more portion appearing on a news story. "(Stevy Maradona's explanation in the interview April 2019). From the aspect of organization, the inclusion of media owner's power has positive and negative values, but according to the editor does not interfere with the independence and neutrality of the media organization. The movement of the media does not become limited or disturbed by Erick Tohir being the head of TKN for the Presidential Candidate candidate number 01. In fact, our circulation jumped during the 2019 Presidential Election campaign period. 1999 About the Press. "(Stevy Maradona's remarks in the interview April 2019)

Facing the possibility of extra media factors, namely the source of the 2019 Presidential Election campaign news whether it is from the national campaign team 01 or the national winning body 02 , Republika is trying to remain in a neutral position. Nothing must or must or must not be covered that limits the narrative in reporting and reporting during the campaign period. Republika has a policy that is quite unique, which has its own policy to provide equal portions. For example, in one story containing 15 paragraphs, Republika continued to assess the quality of the facts and the data that emerged from the field at the time of reporting. Another external factor is the source of advertising, because advertising can influence the direction of reporting. In this study, "So far there have been no changes or abnormalities related to the inclusion of campaign advertisements during the 2019 Presidential Election. Because the General Election Commission (KPU) itself emphasizes the principle of justice for all media. In practice, the KPU divides the portion of the 2019 Presidential Election campaign advertisements equally and is scheduled. "(Stevy Maradona's explanation in the interview April 2019)

That is, Republika still requires its journalists to cover the news of the two pairs of president and vice president (serial numbers 01 and 02 ) as long as the news is worthy of being known by the public. But they turned out to have interesting directions where each member of the Republika editorial was reminded through the signs by the media owner, Erick Thohir, to keep in mind the position of the media owner in the presidential and vice presidential candidate stronghold number 01 . "We have not changed anything related to the composition of 
the team and there is no influence or pressure from Mr. Erick for assigning certain reporters to cover certain news or issues. Pak Erick always emphasizes giving a balanced portion to both the candidate pair and the campaign team. He also reminded every reporter (editorial crew) to know he was on the campaign team serial number 01. "(Stevy Maradona's explanation in the April 2019 interview)

Ideologically, as a newspaper that was founded in the beginning to build the interests of the strength of Muslims who are politically in order to face other forces, since Erick Thohir bought PT. Abdi Bangsa, then Republika experienced an ideological change, which not only carried the ideology of Islam but put forward universialism as reflected in its vision as: "Making the Republika newspaper a trusted Ummah newspaper and prioritizing universal values that are cool, tolerant, peaceful, intelligent and professional but has principles in its involvement in maintaining national unity and the interests of Muslims based on the understanding of Rahmatan lil alamin ". Although its orientation is to strengthen Muslims, its approach is more moderate by trying to develop universal values.

When compared with the conditions before being appointed as head of TKN Erick Thohir's attitude seemed not to have changed its orientation towards the media (Republika). "As I recall from the time of (government) Pak SBY (Soesilo Bambang Yudhoyono, 2004 - 2014), Mr. Erick and his brother, Mr. Boy Thohir, always received invitations to join the government and the ruling party, but he always refused. This fact was told by Mr. Erick himself in the editorial meeting to the meeting of all reporters. For this reason, Erick Thohir accepted the offer. Facing the 212 movement, Erick Tohir lowered a special column, which made his opinion about the movement unrelated to the political agenda, and gave the movement support for peaceful elections, which were the focus of the government to create peaceful elections. Thus this is evidence of the existence of power practices by Republika media owner Erick Thohir appearing in the column on the front page regarding the 212 Reunion action to create a peaceful election, which is the concern of the government. There is a similarity here in the direction of the government campaign with the direction of Eric Tohir's column. "Even though Erick Thohir as the owner of the media affiliated with the incumbent coalition party or presidential and vice presidential candidate pair number 01, Pak Erick as the media owner only reminded him if he was on the party of the candidate, while still instructing him to keep giving a balanced portion with news for presidential and vice presidential candidate pairs number 02. "(Stevy Maradona's explanation in the interview April 2019)

From the news production process that occurs based on interviews and observations, there has been an interaction between individuals involved in news production, namely the media leader as the allocative power holder and the editors and reporters as the allocative power holder. In this interaction the power relations that were built between the media leaders who became the head of the political campaign winning team for pair number 1 , with the operational power holders, according to their acknowledgment did not occur either by the intervention process from individuals involved, due to work routine factors, through organization and comes from extra media. However, looking at the media frame on the economy and politics relating to the government, it is always in a positive perspective that will indirectly benefit the presidential candidate as incumbent. This data shows that in practice media crews have been hegemonyed, to be loyal to the media leaders. The power relations of hegemonic domination, stated by Louw [8], is one form of power relations in which the power practice is an elite alliance with interest groups. In this context, the interest in keeping the media alive and developing even though the political elite here (Erick Thohir) is in the interests of other groups, namely the political interests of winning the Presidential and Vice President Joko Widodo and Maruf Amin. The practice of hegemony itself is mastery which is 
done by mastering the awareness of the members of the group so that its members or in this case the editors and reporters follow the flow of elitist ideology. News that generally benefits one candidate pair is the result of hegemonic practice.

\section{Conclusion}

Republika, as a newspaper with a heart of Islam, has a reader based on the Islamic religion, as the basis of political mass, it will be very meaningful in the contestation of the presidential and vice presidential elections. The inclusion of Republika owners as the head of the winning team for president and vice president incumbent, referring to the instrumentaslis political economy theory, the direction of media content will follow the political orientation of media owners. In the process of building a media frame, the media crew as holders of operational authority claimed that media leaders did not intervene, and they worked with the principles of professional journalism. The media leader only explained how his position as the head of the Presidential Candidate Winning team and Presidential candidates Joko Widodo and Maruf Amin and what their duties and functions were. This relation, gives implicit direction on what should be done by the editors and reporters in producing news. This power relation is the dominant hegemonic relation that constructs the news frame. Outgoing process of building this news frame, appearing in all headlines plus one column framed by Republika provides a smaller portion for a number of problems experienced by the government, which during the 2019 Presidential Election campaign was still led by Joko Widodo as presidential candidate number 01. Instead, the selection and highlighting of the facts of events that are in direct contact with the government, are given a larger portion in the reporting and are wrapped to reflect the government's positive performance.

Republika newspaper reporters have tried to build economic and political news frames during the 2019 Presidential Election campaign period proportionally and did not vilify the presidential and vice presidential candidate pair number 02. However, the alignments over the presidential candidate candidate and vice presidential candidate number 01 were evident in each analysis unit of this study with motives building and trying to direct public opinion to vote. This is in line with the instrumentalist political economy view that media is an instrument of media owners and the direction of media content will be determined by media owners which has been proven. Because the change in orientation of the media owner of the Republika newspaper (Erick Thohir) has caused changes in the content of media content. This means that media owners who are affiliated with a particular political force will have a coherent media content with that political power. This practice is normatively based on the essential function of the media, it will give a loss to the public to be able to obtain balanced and critical information on the process of economic and political development, so it is recommended that the media build editorial independence that is free from various interests.

\section{References}

[1] N. Chomsky. Politik Kuasa Media. Yogyakarta: Pinus Book Publiser, 2006.

[2] Catrina. Pengaruh Orientasi Politik Pemilik Media Terhadap Pemberitaan Televisi. Depok: Universitas Indonesia, 2014.

[3] P. D'Angelo, P. "News Framing as A Multiparadigmatic Research Program: A Response to Entman." Journal of Communication, 2002. 
[4] L.J. Moleong. Metodologi Penelitian Kualitatif. Bandung: PT Remaja Rosdakarya, 2011.

[5] D.A. Scheufele. "Framing as a Theory of Media Effects." International Communication Association, 1999.

[6] R.M. Entman. "Media Framing Biases and Political Power: Explaining slant in news of campaign 2008." Journalism, No. 11, pp. 389, 2010.

[7] J. Curran, M. Gurevitch (Eds.) Mass Media and Society. London: SAGE Publications, 1991.

[8] E.P. Louw. The Media and Cultural Production. London: Sage Publication, 2001. 